\title{
Comparison of Phenol-Chloroform and CTAB Assay for DNA Extraction from Polysaccharides-Rich Simarouba glauca DC Applying Modified CTAB Method
}

\author{
Chetan Kumar Choudhary $^{1 *}$, Santosh Dhillon ${ }^{1}$, K.S. Boora ${ }^{1}$ and Kumar Manoj ${ }^{2}$
}

${ }^{1}$ Department of Molecular Biology and Biotechnology, CCS Haryana Agricultural University, Hisar, 125001, Haryana, India

${ }^{2}$ Department of Botany, Marwari College, Tilka Manjhi Bhagalpur University, Bhagalpur, 812007, Bihar, India

*Corresponding author

\section{A B S T R A C T}

\section{Keywords}

Deoxyribonucleic acid (DNA), Polymerase chain reaction (PCR), Cetyl trimethyl ammonium bromide (CTAB)

Article Info

Accepted: 12 October 2020 Available Online: 10 November 2020
Different methods available for extraction of plant genomic DNA suffers from one or more drawbacks including compromised quality, quantity and many more. The extraction of high-quality DNA Simarouba glauca DC is notoriously troublesome due to the high contents of polysaccharides and different secondary metabolites. Herein, we aimed to develop a modified CTAB extraction method to isolate DNA from tissues containing high levels of polysaccharides. The principle modifications currently employed for DNA extraction involved the use of higher $\mathrm{CTAB}$ concentration with higher levels of $\beta$ mercaptoethanol. Additionally, higher concentrations of sodium chloride and potassium acetate were added simultaneously with absolute ice chilled isopropanol for the precipitation of DNA free from polysaccharides. Absorbance at 260 and $280 \mathrm{~nm}$, respectively, were estimated to check the quality and quantity of the extracted DNA sample. It was found that the presently describe method had good quality, presented mean concentration value $233.93 \pm 61.52 \mathrm{ng} / \mu \mathrm{l}(260 / 280=1.47 \pm 0.2)$. In contrast to modified CTAB method, others method showed mean concentration of $701.52 \pm 80,46,673.01 \pm$ $120.21,431.96 \pm 81.88 \mathrm{ng} / \mu \mathrm{l}$ with absorbance ratios of $1.02 \pm 0.08,0.89 \pm 0.06$ and $1.00 \pm$ 0.07 , respectively. Qualitative assessment of the extracted DNA was checked by Polymerase Chain reaction (PCR) and double digestion of the DNA sample. This method solved the problems of viscous DNA contaminated with polysaccharides, suitable for downstream applications such as restriction, cloning, genetic mapping or marker-assisted breeding.

\section{Introduction}

Simarouba glauca DC is an oil yielding tropical tree belonging to family Simaroubaceae, commonly known as
"Paradise tree" or "Laxmitaru", is a native of Bahamas; Belize; Costa Rica; Cuba; El Salvador; Guatemala; Mexico; Panama; United States but exotic to India, Myanmar, The Phillippines and Srilanka (IUCN, 2019; 
Anita and Praveena, 2020). It grows under tropical conditions in Central America spreading from Mexico to Panama, Southern Florida as well as Caribbean Islands (IUCN RLTS, 2019). In India it was first introduced by National Bureau of Plant Genetic Resources in the research station at Amravati in Maharashtra in 1966 (Hiremath et al., 1996) and to the university of Agricultural Sciences, Bangalore in 1986 by the scientists' Dr Syamasundar Joshi and Dr Shantha Joshi (Joshi and Hiremath, 2000). It is now cultivated in Orrisa, Maharashtra, Karnataka, Gujarat and Tamil Nadu. S. glauca tree has an ability to grow well even in marginal wastelands or dry lands with degraded soil (Anita and Praveena, 2020).

The bark and leaf extract of Simarouba is well known for its different types of pharmacological properties such as haemostatic, antihelmenthic, antiparasitic, antidysentric, antipyretic and anticancerous (Asha Jose et al., 2019, 2020). The main active groups of chemicals in simarouba are called quassinoids. Several of the quassinoids found in Simarouba, such as ailanthinone, glaucarubinone and holacanthone are considered the plant's main therapeutic constituents and are the ones documented to be antiprotozal, antiamebic, antimalarial and even toxic to cancer (Manasi and Gaikwad, 2011; Govindaraju et al., 2009; Saraiva et al., 2006).

Simarouba, apart from being medicinal, is a versatile multipurpose dioecious oil seed tree with a productive potential as high as 2000$2500 \mathrm{~kg}$ oil/ha/year (Joshi and Hiremath, 2000). A kernel of Simarouba yields approximately $75 \%$ of oil and is rich in both unsaturated and saturated fatty acids revealing its suitability for human consumption as well as industrial uses (Armour, 1959; Satpathi, 1984). These plants are polygamodioecious with about $5 \%$ of the population producing exclusively staminate (male) flowers and 40-
$50 \%$ producing mainly male flowers and a few bisexual flowers (andromonoecious) while the remaining $40-50 \%$ produces only the pistillate (female) flowers with sex specific economic value (Armour, 1959; Joshi and Hiremath, 2000; Savitha et al., 2008). Flowering is annual, beginning in December and continuing up to next February and bears fruits during March-April and fruits can be collected in the month of May.

The success of genetic marker system critically depends on superior quality of DNA. The problems encountered in the isolation and purification of DNA especially from Simarouba include co-isolation of highly viscous polysaccharides, degradation of DNA due to endonucleases, inhibitor compounds like polyphenols and other secondary metabolites which directly or indirectly interfere with the enzymatic reactions. However, problems arise because of contaminants Polysaccharides are particularly problematic (Scott and Playford, 1996; Arun et al., 2002). For example, acidic polysaccharides inhibit Hind III enzyme restriction, thereby precluding classic 2primer PCR (Demeke and Adams, 1992; Pandey et al., 1996) by inhibiting Taq DNA polymerase activity (Fang et al., 1992), whereas neutral polysaccharides are not inhibitory (Do and Adams, 1991). Polysaccharides can cause anomalous reassociation kinetics (Merlo and Kemp, 1976). They can also coprecipitate with DNA after alcohol addition during DNA isolation to form highly viscous solutions (Do and Adams, 1991). The DNA is unsuitable for restriction digestion, cloning, PCR and often remains in the wells during electrophoresis. The most effective way to eliminate polysaccharide inhibition is to dilute the DNA extracts, thereby diluting the polysaccharide inhibitors (Pandey et al., 1996). However, excessive dilution of a DNA solution makes it unusable for molecular analysis. 
Different plant texa often may not permit optimal DNA yields from one isolation protocol. For example, some closely related species of the same genus require different isolation protocols. Thus, an efficient protocol for isolation of DNA as well as the optimization of the PCR conditions is required. Various protocols for DNA extraction have been successfully applied to many plant species (Doyle and Doyle, 1987; Ziegenhagen and Scholz, 1993; Sarwat et al., 2006), which were further modified to provide DNA suitable for several kinds of analysis (Wang and Taylor, 1993; Sharma et al., 2000; Arun et al., 2002; Crowley et al., 2003; Chakraborti et al., 2006; Simon et al., 2007; André et al., 2018; Nadia et al., 2019; L. Kidane et al., 2020).

Here we have tested previously established DNA isolation protocols but these methods resulted in DNA with lot of impurities, therefore, we report here a total genomic DNA isolation protocol derived from a method originally developed for other plants (Doyle and Doyle, 1987). Modifications were made to minimize polysaccharide co-isolation and to simplify the procedure for processing large number of samples. The isolated DNA would be suitable for further downstream applications.

\section{Materials and Methods}

\section{Plant material}

Leaves materials of thirty two genotypes of Simarouba which comprises of sixteen male and sixteen female plants, scored on the basis of their floral morphology, were collected from various geographical locations of India. The SGG genotypes were collected from Gujrat, SGH genotypes from Haryana, PALEM genotypes from Andhra Pradesh and PDKVSG genotypes from Maharashtra (Table 1). Leaf samples of approx. 20 gram per plant were collected and stored at $-80^{\circ} \mathrm{C}$ within 30 hour of being collected until the DNA was sampled.

\section{DNA isolation}

Two commonly used DNA isolation method viz., CTAB method and Phenol-Chloroform method were tried in beginning. Taking clue from initial results, CTAB method was modified as follows (Table 2).

\section{Reagents and solutions}

An extraction buffer consisting of 3\% CTAB $(\mathrm{w} / \mathrm{v}), \quad 10 \mathrm{mM}$ Tris- $\mathrm{HCl}(\mathrm{pH} \quad 8.0), 20 \mathrm{mM}$ EDTA $(\mathrm{pH} 8.0), 5 \mathrm{M} \mathrm{NaCl}, 3 \mathrm{M}$ potassium acetate, $2 \% \quad \mathrm{PVP}$ and $0.3 \% \quad \beta$ mercaptoethanol (v/v) was prepared. Ribonuclease A $(10 \mathrm{mg} / \mathrm{ml})$, chloroformisoamylalcohol (24:1) (v/v), Ethanol (70\%), TE buffer (10Mm Tris-HCl, 1mM EDTA, $\mathrm{pH}$ 8.0) and isopropanol are the additional solutions required.

\section{DNA isolation protocol}

$5 \mathrm{~g}$ of leaf sample were taken from each sample was ground in liquid nitrogen using a mortar and pestle. The pulverized leaves were quickly transferred to $10 \mathrm{ml}$ of freshly prepared pre-warmed $\left(65^{\circ} \mathrm{C}\right)$ extraction buffer and shaken vigorously by inversion to form slurry. The tubes were incubated at $65^{\circ} \mathrm{C}$ in water bath for 60-90 minutes with intermittent shaking for every 10 minutes. 2. The mixture was cooled to room temperature, an equal volume of chloroform: isoamyl alcohol (24:1) was added and mixed properly by gently inversion for 20 minutes, subsequently centrifuged at 12,000 rpm for 15 minutes at $4^{\circ} \mathrm{C}$ to separate the phases (long term mixing of samples in chloroform: isoamyl alcohol will help in removal of pigments and formation of brownish color in DNA sample can be omitted). 3. The supernatant was 
carefully decanted and transferred to a fresh tube and the chloroform: isoamyl alcohol step was repeated until a clear supernatant was obtained. An equal volume of $5 \mathrm{M} \mathrm{NaCl}$ was added to supernatant and mixed gently. Successively, add $1 / 10$ the volume $3 \mathrm{M}$ potassium acetate and followed by the addition of one volume cold isopropanol ($20^{\circ} \mathrm{C}$ ) to precipitate the fibrous DNA. 4. The mixture was incubated at $-20^{\circ} \mathrm{C}$ for a minimum of 30 minutes, centrifuged at $12,000 \mathrm{rpm}$ for 10 minutes, the resulting pellet was washed with $70 \%$ ethanol, air dried and dissolved in 500 $\mu 1$ of TE buffer. 5. Two $\mu 1$ of RNase was added to each sample, which was then incubated for overnight at $37^{\circ} \mathrm{C}$, mixed with an equal volume of chloroform: isoamyl alcohol, and centrifuged at 12,000 rpm for 10 minutes at room temperature. The aqueous layer was transferred to a fresh tube followed by washing with an equal volume of chloroform alone by centrifuging at 12,000 rpm for 15 minutes. 6. The supernatant was transferred to a fresh tube and DNA was precipitated using 1.0 volume of chilled isopropanol, 0.5 volumes of $5 \mathrm{M} \mathrm{NaCl}$ and 0.1 volume of $3 \mathrm{M}$ potassium acetate, the resulting pellet, obtained after centrifugation at 12,000 rpm for 15 minutes, was dissolved in $500 \mu \mathrm{l}$ TE buffer.

\section{Quantity and quality of DNA}

The yield of DNA per gram of leaf tissue extracted was quantified using a UV spectrophotometer. The purity of DNA was determined by calculating the ratio of absorbance at $260 \mathrm{~nm}$ to that of $280 \mathrm{~nm}$. DNA quality and quantity was also determined by running the samples on $0.8 \%(\mathrm{w} / \mathrm{v})$ agarose gel based on the intensities of band when compared with the $\lambda$ DNA marker.

\section{Restriction digestion}

One $\mu \mathrm{g}$ of genomic DNA was digested over night with one units of each of restriction enzymes, EcoR1 and BamH1, individually. Restriction was carried out in a provided buffered solution at $37^{\circ} \mathrm{C}$ following manufacture's protocol (Fermentas, Canada). Digested DNA were electrophorosed on $0.8 \%$ agarose gel along with undigested genomic DNA and double digested (EcoR1/BamH1).

\section{PCR amplification}

Polymerase Chain Reactions were carried out using the extracted DNA samples in order to check the proficiency of the extracted DNA and also to check whether any inhibitory component were present in the samples which may hinder the participation of the DNA in PCR reactions. PCR amplification was carried out in a G-STORM (programmable thermal cycler) to amplify the specific DNA sequence, in a reaction volume of $25 \mu$ containing $1 \mathrm{X}$ PCR buffer, $0.2 \mathrm{mM}$ each dNTP mix, $2.5 \mathrm{mM}$ $\mathrm{MgCl}_{2}, \quad 1.0 \mathrm{U}$ Taq DNA polymerase (Fermentas, USA), 50ng of template DNA and $\quad 0.8 \mu \mathrm{M} \quad$ UBC-815 (5'CTC TCT CTC TCT CTC TG-3') ISSR (UBC primer set 9, Biotechnology Laboratory, The University of British Columbia, Canada) primers. The amplification conditions were: initial denaturation for $5 \mathrm{~min}$ at $95^{\circ} \mathrm{C}$, followed by 35 cycles of $60 \mathrm{~s}$ denaturation at $94^{\circ} \mathrm{C}, 45 \mathrm{~s}$ annealing at $55^{\circ} \mathrm{C}$ and $45 \mathrm{~s}$ extensions at $72^{\circ} \mathrm{C}$. Final extension step was at $72^{\circ} \mathrm{C}$ for $10 \mathrm{~min}$.

The amplification products were resolved on $1.5 \%(\mathrm{w} / \mathrm{v})$ agarose gels, in $1 \mathrm{X}$ TBE buffer and then stained with Ethidium Bromide. Gels with amplification fragments were documented using Gel documentation system (Biorad, USA).

\section{Data analysis}

Data were analyzed, DNA concentration and absorbance at 260/280, using the Microsoft Excel®. Experimental results, presented as Mean \pm SEM (Standard Error Mean) and AP- 
value $<0.05$ was considered statistically significant, were used to compare the quality and quantity between the extraction methods.

\section{Results and Discussion}

Samples extracted by the presently describe method showed a mean concentration of $233.93 \pm 61.52 \mathrm{ng} / \mu \mathrm{l}$ (Table 3 and Figure 5) with $\mathrm{A}_{260 / 280}$ ratios of $1.47 \pm 0.2$, respectively (Table 3 and Figure 4). Samples extracted by other methods had a mean concentration of $701.52 \pm 80.46,673.01 \pm 120.21,431.96 \pm$ $81.88 \mathrm{ng} / \mu \mathrm{l}$ (Table 3 and Figure 5) with $\mathrm{A}_{260 / 280}$ ratios of $1.02 \pm 0.08,0.89 \pm 0.06$ and $1.00 \pm 0.07$, respectively (Table 3 and Figure 4). Although the concentration of the samples extracted by the describe method was on average lower, $233.93 \pm 61.52$ versus 701.52 $\pm 80.46 \mathrm{ng} / \mu \mathrm{l} ; p<0.05$, it was also observed that they had lower standard deviation (Table 3). In all discussed methods, there are different distinct concentration values: in extraction by the method 4 , the concentration ranges, approximately, from 115.89 - 304.05 $\mathrm{ng} / \mu \mathrm{l}$, while with the method 1 , from 589.74 $753.87 \mathrm{ng} / \mu \mathrm{l}$; method 2, from 528.52 - 798.37 $\mathrm{ng} / \mu \mathrm{l}$ and method 3, from 323.08 - 498.67 ng/ $\mu 1$, respectively (Table 3 ). Table 3 shows the ratios of absorbance at 260/280 in method 4 ranges, approximately, from $1.10-1.66$, whereas other thee method showed range, from .94 - 1.03, 0.83 - 0.96, 0.96 - 1.11, respectively. The 260/280 ratio values observed in the samples extracted by the presently describe method are higher than other methods found in the extraction $(p<$ $0.05)$.

Different degrees of smeared (Figure 1a) and fire type bands visualized (Figure 1b), indicated high levels of polysaccharides and protein impurities in the samples isolated from phenol-chloroform method compared to unmodified CTAB method (Figure 1c) and modified CTAB method (Figure 1d).
The restriction digestion of isolated standard DNA samples with one unit of enzyme per microgram of DNA sample shows complete digestion (Figure 2). Less clear or blurred PCR amplification pattern was observed with DNA samples isolated from modified phenolchloroform method, whereas clear and intact banding pattern was observed with modified CTAB method (Figure 3).

Different methods need for different plants that contain diverse secondary compounds that interfere with the extraction (Croy et al., 1993). In the present study, among the two protocols examined, CTAB method (Doyle and Doyle, 1987) and Phenol-Chloroform (Sarwat et al., 2006), modified CTAB method proved efficacious compared to modified Phenol-Chloroform method. Isolation of DNA from Simarouba is difficult due to presence of high level of mucous, polysaccharides, pigments and other secondary metabolites. Several methods on removal of polysaccharides from DNA have been extensively reviewed of which salt precipitation found to be most effective (Arun et al., 2002; Crowley et al., 2003; Sarwat et al., 2006; Nadia et al., 2019). In the view of above, several modifications were introduced to $\mathrm{CTAB}$ method for the removal of impurities called modified CTAB method, employing increased salt concentrations with proportional increase in CTAB concentration, in the extraction buffer along with successive long-term chloroform: isoamyl alcohol extractions, an overnight RNase treatment, purification with equal volume of chloroform: isoamyl alcohol and then chloroform alone and final re-precipitation with salt $(5 \mathrm{M} \mathrm{NaCl}$ and $3 \mathrm{M}$ potassium acetate) proved very effective (Table 2 and Figure 1d). CTAB buffer with $\beta$-mercaptoethanol, successfully removed polyphenols (Horne et al., 2004; Li et al., 2007) giving rise a clear translucent DNA pellet. Successive purification with chloroform: isoamyl and washing with 
chloroform alone excluded the CTABpolysaccharides complex and protein impurities (Chakraborti et al., 2006; Simon et al., 2007). In the present standardized protocol, $5 \mathrm{M} \mathrm{NaCl}$ and $3 \mathrm{M}$ potassium acetate, successfully removed polysaccharides impurities from DNA at the end of the process ensured complete removal of residual of polysaccharides in the sample (Sharma $e t$ al., 2000; Paterson et al., 1993). This step proved very critical for the recovery of pure DNA in the entire isolation process and visualized as a distinct or intact intense band very close to the gel well (Figure 1d).

Table.1 List of accessions used in the present studies

\begin{tabular}{|c|c|c|c|c|}
\hline \multirow[t]{2}{*}{ S.No. } & \multirow[t]{2}{*}{ Accession Code } & \multicolumn{2}{|l|}{ Gender } & \multirow{2}{*}{$\begin{array}{l}\text { Sample collectior } \\
\text { Site }\end{array}$} \\
\hline & & Female & Male & \\
\hline 1. & SGH-01 & $\mathrm{F}$ & M & Haryana. \\
\hline 2. & SGH-02 & $\mathrm{F}$ & $\mathrm{M}$ & Haryana. \\
\hline 3. & SGH-03 & $\mathrm{F}$ & M & Haryana. \\
\hline 4. & SGH-04 & $\mathrm{F}$ & M & Haryana. \\
\hline 5. & SGH-05 & $\mathrm{F}$ & M & Haryana. \\
\hline 6. & SGG-01 & $\mathrm{F}$ & $\mathrm{M}$ & Gujrat. \\
\hline 7. & SGG-02 & $\mathrm{F}$ & M & Gujrat. \\
\hline 8. & SGG-03 & $\mathrm{F}$ & M & Gujrat. \\
\hline 9. & SGG-04 & $\mathrm{F}$ & M & Gujrat. \\
\hline 10. & SGG-05 & $\mathrm{F}$ & M & Gujrat. \\
\hline 11. & PALEM-01 & $\mathrm{F}$ & M & Andhra Pradesh \\
\hline 12. & PALEM-02 & $\mathrm{F}$ & M & Andhra Pradesh \\
\hline 13. & PALEM-03 & $\mathrm{F}$ & M & Andhra Pradesh \\
\hline 14. & PALEM-04 & $\mathrm{F}$ & M & Andhra Pradesh \\
\hline 15. & PDKVSG-23 & $\mathrm{F}$ & M & Maharashtra. \\
\hline 16. & PDKVSG-30 & $\mathrm{F}$ & M & Maharashtra. \\
\hline
\end{tabular}

Table.2 Modification tried out for the optimization of DNA extraction in Simarouba glauca

\begin{tabular}{|c|c|c|}
\hline Method & Modification & Results \\
\hline \multirow{4}{*}{$\begin{array}{l}\text { CTAB method, } \\
\text { Doyle and Doyle } \\
(1987)\end{array}$} & Without any modification & $\begin{array}{l}\text { Fire type bands on gel indicating } \\
\text { polysaccharides and protein contamination }\end{array}$ \\
\hline & $\begin{array}{l}\text { Increased salt concentrations in the extraction } \\
\text { buffer ranging from } 1.4 \mathrm{M} \mathrm{NaCl} \text { to } 3 \mathrm{M} \mathrm{NaCl} \text { with } \\
\text { proportional increase in } \mathrm{CTAB} \text { concentration. }\end{array}$ & $\begin{array}{l}2 \mathrm{M} \mathrm{NaCl} \text { with } 3 \% \mathrm{CTAB} \text { provided } \\
\text { efficient removal of major polysaccharides }\end{array}$ \\
\hline & $\begin{array}{l}\text { Chloroform: isoamyl step until a clear supernatant; } \\
\text { Overnight RNase treatment; Purification with equal } \\
\text { volume of chloroform: isoamyl and washing with } \\
\text { equal volume of chloroform alone }\end{array}$ & $\begin{array}{l}\text { Eliminated the protein, } \\
\begin{array}{l}\text { contaminations along with } \\
\text { polysaccharides complex. }\end{array}\end{array}$ \\
\hline & Precipitation with $5 \mathrm{M} \mathrm{NaCl}$ salt. & Elimination of residual polysaccharides. \\
\hline \multirow{3}{*}{$\begin{array}{l}\text { Phenol-chloroform } \\
\text { method, Maryam } \\
\text { Sarwat et al., } \\
(2006)\end{array}$} & Without any modification & $\begin{array}{l}\text { Sheared bands on gel indicating higher } \\
\text { protein and polysaccharide contamination. }\end{array}$ \\
\hline & $\begin{array}{l}\text { Salt concentration increased from } 0.1 \mathrm{M} \text { to } 1.4 \mathrm{M} \text { in } \\
\text { the extraction buffer. }\end{array}$ & $\begin{array}{l}\text { Viscous and firetype bands on gel as } \\
\text { compared to CTAB method. }\end{array}$ \\
\hline & Additional phenols:chloroform extraction & Insufficient protein removal. \\
\hline
\end{tabular}


Table.3 Evaluations of samples extracted using phenol-chloroform, CTAB and currently describe method according to spectral absorbance ratio $\left(\mathrm{A}_{260 / 280}\right)$, concentration $(\mathrm{ng} / \mu \mathrm{L})$,

DNA quality, color and PCR amplification

\begin{tabular}{|c|c|c|c|c|c|}
\hline Sample & $\mathbf{A}_{260 / 280}$ & Ce $(\mathrm{ng} / \mu \mathrm{L})$ & ${ }^{1}$ Quality & ${ }^{2}$ Color & ${ }^{3} \mathbf{P C R}$ \\
\hline \multicolumn{6}{|c|}{ Unmodified phenol-chloroform (Method 1) } \\
\hline SGH-01F, M & 0.94 & 589.34 & $\mathrm{III}_{\mathrm{S}}$ & III & II \\
\hline SGG-01F, M & 1.03 & 697.45 & $\mathrm{III}_{\mathrm{S}}$ & III & II \\
\hline PALEM-01F, M & 0.97 & 753.87 & $\mathrm{III}_{\mathrm{S}}$ & III & II \\
\hline PDKVSG-23F, M & 1.12 & 765.43 & $\mathrm{III}_{\mathrm{S}}$ & III & II \\
\hline Average & 1.02 & 701.52 & - & - & - \\
\hline Standard Deviation & 0.08 & 80.46 & . & - & - \\
\hline Standard Error & 0.04 & 40.23 & & - & - \\
\hline \multicolumn{6}{|c|}{ Modified phenol-chloroform (Method 2) } \\
\hline SGH-01F, M & 0.83 & 798.37 & III & III & II \\
\hline SGG-01F, M & 0.92 & 528.52 & III & III & II \\
\hline PALEM-01F, M & 0.85 & 625.23 & III & III & II \\
\hline PDKVSG-23F, M & 0.96 & 739.95 & III & III & II \\
\hline Average & 0.89 & 673.01 & - & - & - \\
\hline Standard Deviation & 0.06 & 120.21 & - & - & - \\
\hline Standard Error & 0.03 & 60.10 & - & - & - \\
\hline \multicolumn{6}{|c|}{ Unmodified CTAB (Method 3) } \\
\hline SGH-01F, M & 0.98 & 415.01 & II & II & II \\
\hline SGG-01F, M & 0.96 & 489.67 & II & II & II \\
\hline PALEM-01F, M & 0.96 & 323.08 & II & II & II \\
\hline PDKVSG-23F, M & 1.11 & 500.09 & II & II & II \\
\hline Average & 1.00 & 431.96 & - & - & - \\
\hline Standard Deviation & 0.07 & 81.88 & - & - & - \\
\hline Standard Error & 0.03 & 40.94 & - & - & - \\
\hline \multicolumn{6}{|c|}{ Modified CTAB [presently describe] (Method 4) } \\
\hline SGH-01 F, M & 1.59 & 119.09 & I & I & I \\
\hline SGH-02 F, M & 1.08 & 293.08 & I & I & I \\
\hline SGH-03 F, M & 1.13 & 245.05 & I & I & I \\
\hline SGH-04 F, M & 1.66 & 289.09 & I & I & I \\
\hline SGH-05 F, M & 1.66 & 278.07 & I & I & I \\
\hline SGG-01 F, M & 1.60 & 115.89 & I & I & I \\
\hline SGG-02 F, M & 1.65 & 298.54 & I & I & I \\
\hline SGG-03 F, M & 1.56 & 200.65 & I & I & I \\
\hline SGG-04 F, M & 1.10 & 199.97 & I & I & I \\
\hline SGG-05 F, M & 1.57 & 275.78 & I & I & I \\
\hline PALEM-01 F, M & 1.59 & 240.07 & I & I & I \\
\hline PALEM-02 F, M & 1.57 & 153.47 & I & I & I \\
\hline PALEM-03 F, M & 1.36 & 219.04 & I & I & I \\
\hline PALEM-04 F, M & 1.51 & 267.09 & I & I & I \\
\hline PDKVSG-23 F, M & 1.50 & 304.05 & I & I & I \\
\hline PDKVSG-30 F, M & 1.37 & 243.97 & I & I & I \\
\hline Average & 1.47 & 233.93 & - & - & - \\
\hline Standard Deviation & 0.02 & 61.52 & - & - & - \\
\hline Standard Error & 0.05 & 15.38 & - & - & - \\
\hline
\end{tabular}

(I) Low-molecular weight, no fire type and no degradation - good quality DNA; (II) Thick, less fire type and less degradation - medium quality DNA; (III) High-molecular weight, highly viscous, high fire type or medium degraded- poor quality DNA; $\left(\mathrm{III}_{\mathrm{S}}\right)$ High-molecular weight, highly viscous, sheared type or degraded- poor quality DNA.

${ }^{2}$ (I) Transparent; (II) Yellowish or Light brown; (III) Dark brown.

${ }^{3}$ PCR amplification: (I) Good amplification; (II) Medium amplification. 


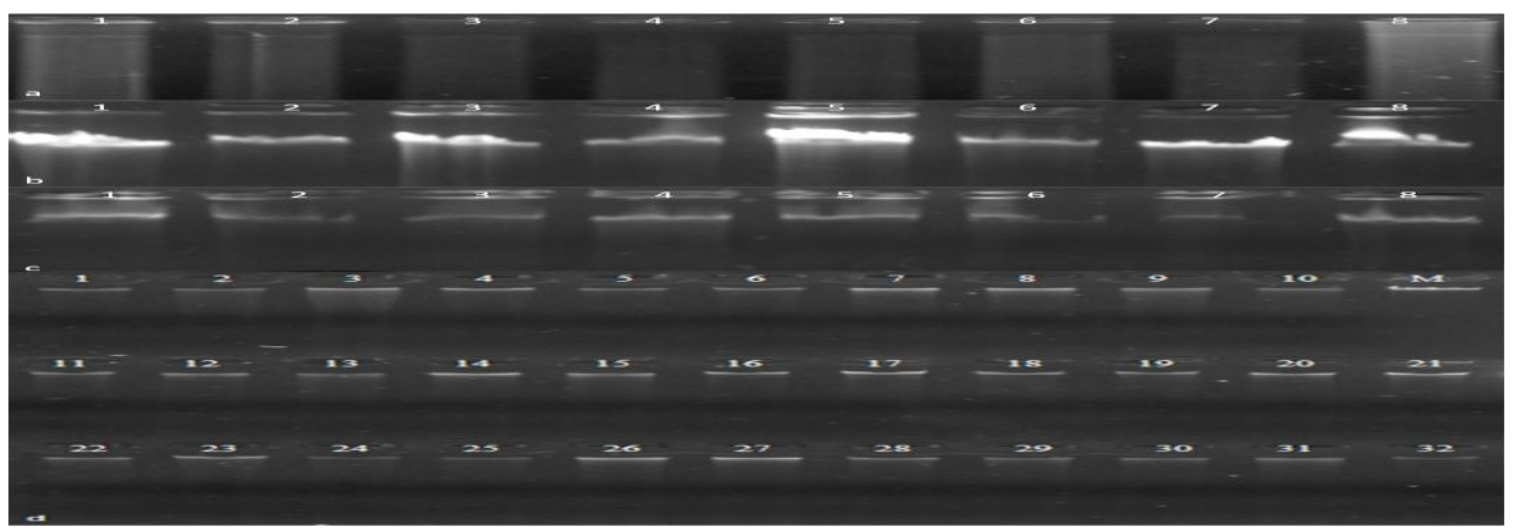

Figure.1 Electrophoretic pattern of DNA samples showing : (a) Sheared type bands isolated using unmodified phenol-chloroform method. (b) Viscous fire type bands isolated using modified phenol-chloroform method. (c) Less fire type bands isolated using CTAB method. (d) Distinct, clear and sharp bands isolated using presently describe method; M : Standard Lamda DNA ( 100ng/ $\mu 1$ ).

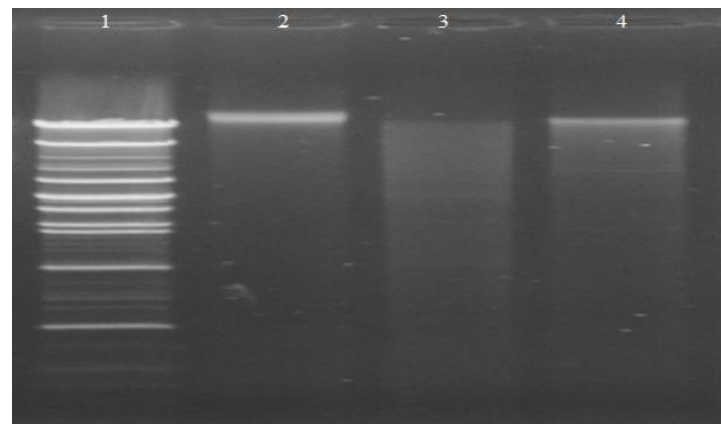

Figure.2 Restriction digestion of DNA extracted from leaves of Simarouba using the currently optimized protocol. Lane 1. Lambda DNA double digests with restriction enzymes EcoR1+BamH1. Lane 2. Undigested genomic DNA. Lane 3 and 4. Genomic

DNA digested with EcoR1 and BamH1, respectively.

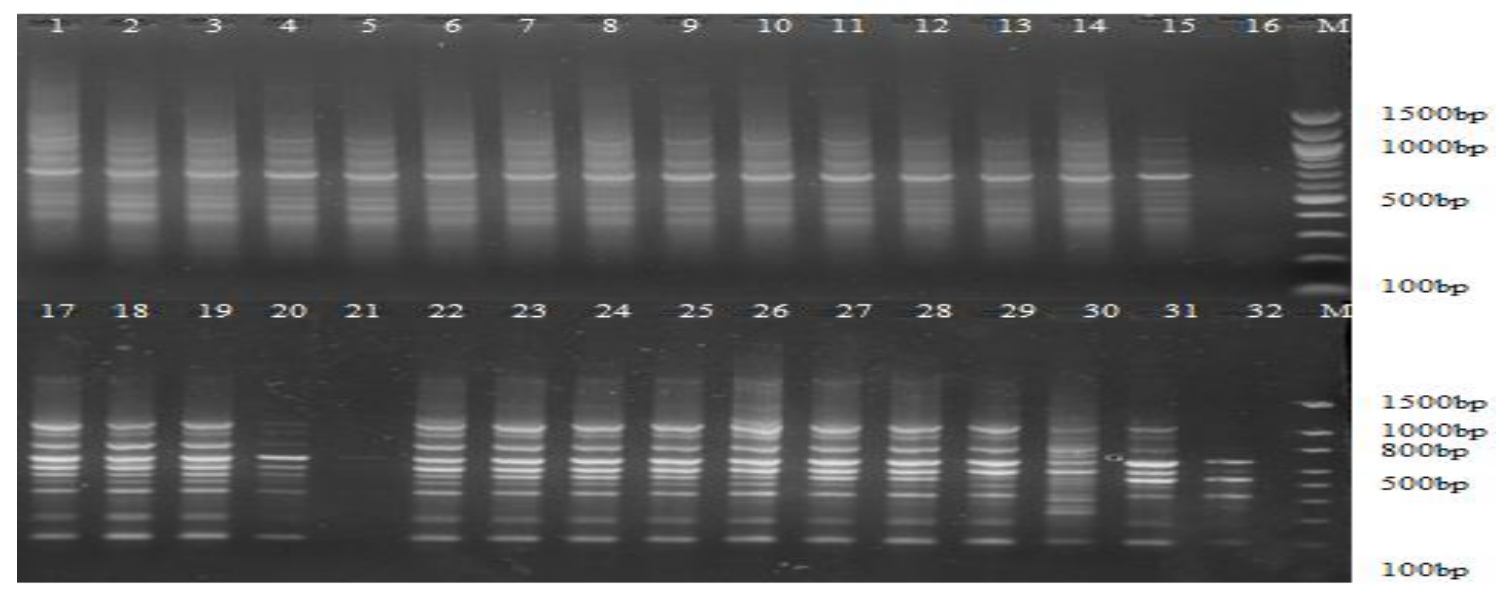

Figure.3 Evaluation of PCR amplification of samples extracted using modified phenolchloroform (Lane 1-8), CTAB (Lane 9-16) and currently describe method (Lane 17-32) using ISSR primer ISP-13, M: Standard 100bp DNA Ladder 


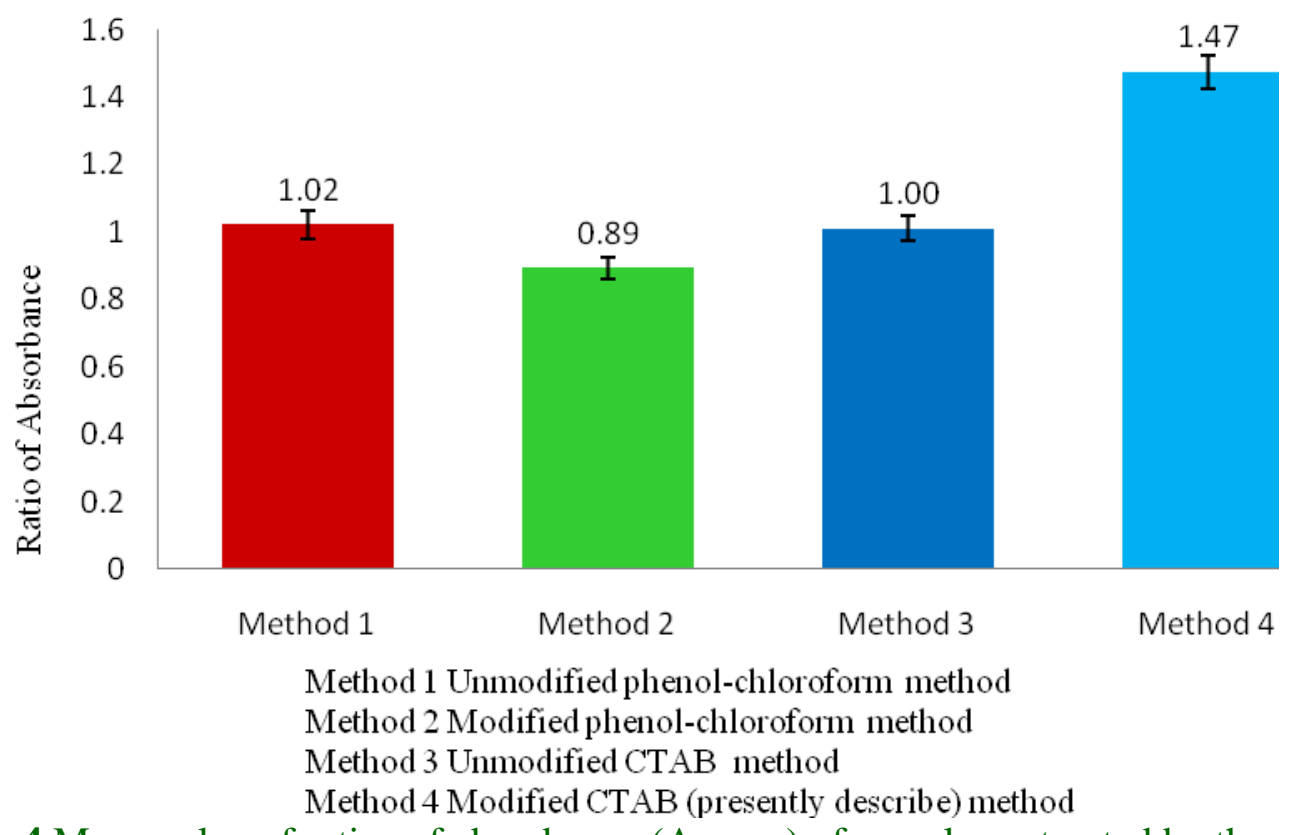

Figure.4 Mean value of ratios of absorbance $\left(\mathrm{A}_{260 / 280}\right)$ of samples extracted by the presently describe method $(* \mathrm{p}<0.05)$

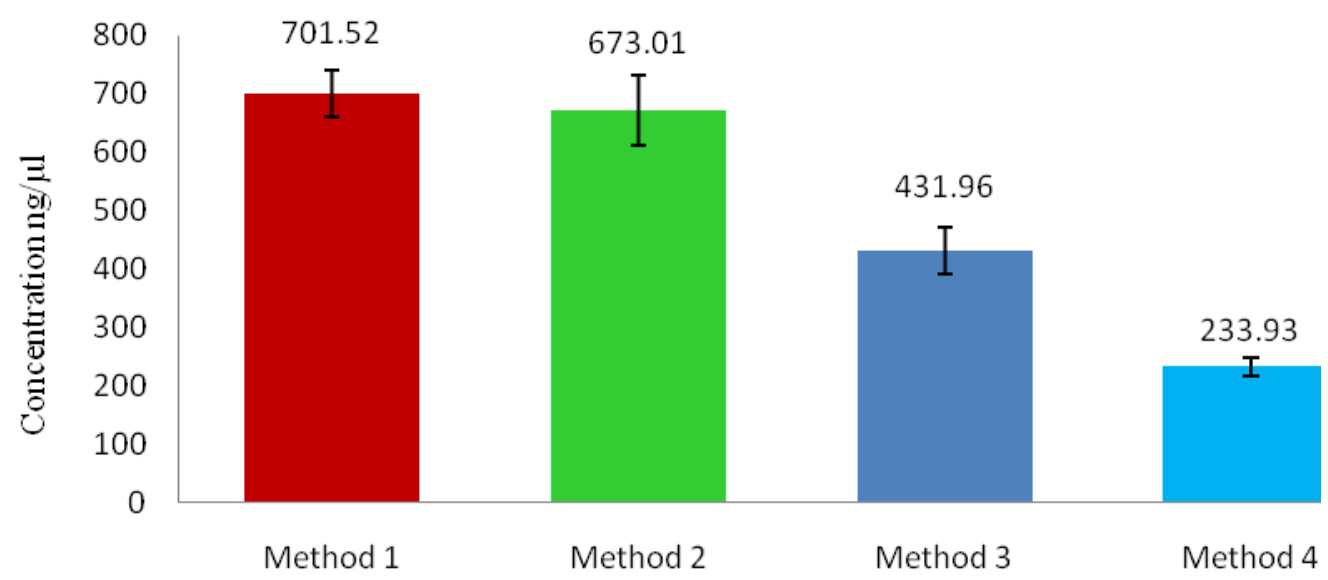

Method 1 Unmodified phenol-chloroform method

Method 2 Modified phenol-chloroform method

Method 3 Unmodified CTAB method

Method 4 Modified CTAB (presently describe) method

Figure.5 Mean values of the concentrations of samples extracted by the presently describe method

The extracted DNA was of high quality as it showed a reading of between " 1.08 to 1.66 (mean 1.47)", after calculating the absorbance at $260 \mathrm{~nm}$ to that of $280 \mathrm{~nm}$ (Table 3). The purity of extracted DNA was reconfirmed by subjecting the isolated DNA to restriction digestion showed that the extracted DNA samples were free from any inhibitory and interfering compounds (Figure 2). Furthermore, agarose gel containing PCR products showed less clear or blurred banding pattern with DNA samples isolated from modified phenol-chloroform method, whereas clear and prominent banding pattern was observed with modified CTAB method. PCR product of modified CTAB method produced 
strong and reliable amplification in all the samples, demonstrating the quality and purity of the extracted DNA (Figure 3).

In conclusions, the principle modifications currently employed for DNA extraction involved the use of higher CTAB concentration and higher levels of $\beta$ mercaptoethanol. Additionally, higher concentrations of sodium chloride and potassium acetate were added simultaneously with absolute ice cold isopropanol for the precipitation of DNA free from polysaccharides. The prescribed modifications in the present method establish a quick and efficient standardized protocol for DNA extraction from different polysaccharide rich plant orders.

\section{Acknowledgement}

The author thank Department of Science and Technology (DST), Government of India for funding and Dr. S. Joshi (Retd.), University of Agricultural Sciences, GKVK, Bangalore and Dr. R.R. Shakhela, SD Agricultural University, Dantiwada for providing material and valuable suggestions.

\section{References}

Andre Luis F. Santos, Carolina Q. P. Oliveira, Geovana Nicole P. N. Arruda, John Kenned Martins. 2018. Comparison of DNA extraction using proteinase $\mathrm{K}$ and extraction kit: analysis of the quality of the genetic material. J. Bras Patol Med Lab. 54(2): 70-75.

Anita B. R. and Praveena B. 2020. A review on anti-cancer potential of phytochemicals isolated from Simarouba Glauca. Indo American journal of pharmaceuticals sciences. 07(4): 281-286.

Armour, R.P. 1959. Investigations on Simarouba glauca DC in El Salvador.
Econ. Bot. 13, 41-66.

Arun Dev Sharma, Prabhjot Kaur Gill and Prabhjeet Singh. 2002. DNA Isolation From Dry and Fresh Samples of Polysaccharide-Rich Plants. Plant Molecular Biology Reporter. 20, 415a415f.

Asha Jose, Elango Kannan, Palur Ramakrishnan Anand Vijaya Kumar, SubbaRao Venkata Madhunapantula. 2019. Therapeutic Potential of Phytochemicals Isolated from Simarouba glauca for Inhibiting Cancers: A Review, Sys. Rev. Pharm. 10(1): 73-80.

Asha Jose, Elango Kannan, SubbaRao V. Madhunapantula. $2020 . \quad$ Antiproliferative potential of phytochemical fractions isolated from Simarouba glauca DC leaf. Heliyon. 6, e03836.

Chakraborti, D., Sarkar, A., Gupta, S. and Das, S. 2006. Small and large scale genomic DNA isolation protocol for chickpea (Cicer arietinum L.) suitable formolecular marker and transgenic analysis. African journal of Biotechnology. 5(8): 585-589.

Crowley, T.M., Murlitharan, M.S. and Stevenson, T.W. 2003. Isolating conifer DNA: A Superior polysaccharide elimination method. Plant Mol. Bio. Rep. 21: 97a-97d.

Croy, E.J., Ikemura, T., Shirsat, A. and Croy, R.D. 1993. Plant Nucleic Acids, Plant Mole. Bio., Bios Scientific Publishers, Blackwell Scientific Publications, U.K. http://dx.doi.org/10.1016/b978-0-08091753-5.50008-1.

De Saraiva, R.C.G., Pinto, A.C., Nunomura, S.M., Pohlit, A.M. 2006. Triterpenos e alcaloide tipo cantinona dos galhos de Simaba polyphylla (Cavalcante) WW Thomas (Simaroubaceae). Quim. Nova. 29, 264-268.

Demeke, T. and Adams, R.P. 1992. The effect of plant polysaccharides and buffer 
additives of PCR. Biotechniques. 12, 332-334.

Do, N. and Adams, R.P. 1991. A simple technique of removing plant polysaccharides contaminants from DNA. Biotechniques. 10, 162-166.

Doyle, J.J. and Doyle, J.L. 1987. A rapid DNA isolation procedure for small quantities of fresh leaf tissue. Phytochem. Bull. 19, 11-15.

Fang, G., Hammer, S. and Groumet, R. 1992. A quick and inexpensive method for removing polysaccharides from plant genomic DNA. Biofeedback. 13, 52-54.

Govindaraju, K., Darukeshwara, J., Srivastava, A.K. 2009. Studies on protein characteristics and toxic constituents of Simarouba glauca oilseed meal. Food Chem. Oxicol. 47(6): 1327-1332.

Hiremath, S., Joshi, S., Shambhulingappa, K.G., Channakrishnaian, K.M., Chikkadevaiah, Jagannath, D.P. and Sennappa, K.K. 1996. J. oilseed Res. 13, 93-96.

Horne, E.C., Kumpatla, S.P., Patterson, M.G., Thompson, S.A. 2004. Improved highthroughput sunflower and cotton genomic DNA extraction and PCR fidelity. Plant Mol Biol Rep. 22, 83.

IUCN Red List of Threatened Species. 2019. e.T150108258A150108260.

Joshi, S. and Hiremath, S. 2000. Simarouba-A potential oilseed tree. Current Science. 78(6): 694-697.

Letebrhan Kidane, Marie Kalousova and Hewan Demissie. 2020. Comparison and optimization for DNA extraction of okra (Abelmoschus esculentus L. Moench). African Journal of Biotechnology. 19(6): 353-361.

Li, J.T., Yang, J., Chen, D.C., Zhang, X.L., Tang, Z.S. 2007. An optimized minipreparation method to obtain highquality genomic DNA from mature leaves of sunflower. Genet Mol Res. 6,
1064.

Manasi, P.S. and Gaikwad, D.K. 2011. A critical review on Medicinally Important Oil Yielding plant Laxmitaru (Simarouba glauca DC). J. Pharm. Sci. and Res. 3(4): 1195-1213.

Merlo, D.J. and Kemp, J.D. 1976. Effect of polysaccharides on kinetics of DNA. Plant Physiol. 58, 1522-1526.

Murray, M.G. and Thompson, W.F. 1980. Rapid isolation of high molecular weight DNA. Nucleic Acid Res. 8, 4321-4325.

Nadia Aboul-Ftooh Aboul-Maaty and Hanaa Abdel-Sadek Oraby. 2019. Extraction of high-quality genomic DNA from different plant orders applying a modified CTAB-based method. Bulletin of the National Research Centre. 43, 25.

Pandey, R.N., Adams, R.P. and Flournoy, L.E. 1996. Inhibitions of random amplified polymorphic DNAs (RAPDs) by plant polysaccharides. Plant Mol Biol Rep. 14, 17-22.

Paterson, A.H., Brubaker, C.L. and Weendel, J.F. 1993. A rapid method for extraction of Cotton (Gossypium sp.) genomic DNA suitable for RFLP or PCR analysis. Plant Mol. Bio.Rep. 11, 122127.

Peterson, D.G., Boehm, K.S. and Stack, S.M. 1997. Isolation of milligram quantities of nuclear DNA from tomato (Lycopersicon esculentum), a plant containing high levels of polyphenolic compounds. Plant Mol. Biol. Rep. 15, 148-153.

Porebski, S., Baily, L.G. and Baum, B.R. 1997. Modification of a CTAB DNA extraction protocol for plants containing high polysaccharide and polyphenol components. Plant Mol. Biol. Rep. 15, 8-15.

Sarwat, M., Negi, M.S., Kumaran, M.L., Tyagi, A.K., Das, S. and Srivastava, P.S. 2006. A standardized protocols for 
genomic DNA isolation from Terminalia arjuna for genetic diversity analysis. Electronic journal of Biotechnology. 9(1): 86-91.

Satpathi, B. 1984. Simarouba glaucaan oilyielding tree. Indian Farming. 34, 22-3.

Savitha, J.G., Sudarshana, L., Joshi, S. Hiremath, S. and Ramachandra, G. 2008. Development of biochemical and molecular markers for polygamodioecious character in Simarouba glauca DC. Int. J. Biotech. Biochem. 4, 233-42.

Scott, K.D. and Playford, J. 1996. DNA extraction technique for $\mathrm{PCR}$ in rain forest plant species. Biotechniques, 20, 974-978.

Sharma, K.K., Lavanya, M. and Anjaih, V. 2000. A method for isolation and purification of peanut genomic DNA suitable for analytical application. Plant Mol. Bio.Rep. 18, 393a-393h.

Simon, L., Shyamalamma, S. and Narayanaswamy, $\quad$ P. 2007. Morphological and molecular analysis of genetic diversity in jackfruit. Journal of Horticultural Sciences and Biotechnology. 82, 764-768.

Wang, Y. and Taylor, D.E. 1993. A rapid CTAB DNA isolation technique useful for RAPD fingerprinting and other PCR applications. Biotechniques. 14, 748750.

Ziegenhagen, B. and Scholz, F. 1993. A procedure for mini-preparation of genomic DNA from needles of silver fir (Abies alba Mill.). Plant Mol. Biol. Rep. 11, 117-121.

\section{How to cite this article:}

Chetan Kumar Choudhary, Santosh Dhillon, K. S. Boora and Kumar Manoj. 2020. Comparison of Phenol-Chloroform and CTAB Assay for DNA Extraction from Polysaccharides-Rich Simarouba Glauca DC Applying Modified CTAB Method. Int.J.Curr.Microbiol.App.Sci. 9(11): 1547-1558. doi: https://doi.org/10.20546/ijcmas.2020.911.183 